\title{
25 Research Square \\ Reinfection with SARS-CoV-2 in a splenectomized patient from Kocaeli, Turkey
}

Müge Toygar Deniz ( $\nabla$ mugedeniz90@gmail.com )

Kocaeli University https://orcid.org/0000-0002-6946-2727

\section{Sila Akhan}

Kocaeli University https://orcid.org/0000-0002-2540-2060

\section{Melih Berkay Esgin}

Kocaeli University

\section{Murat Sayan}

Kocaeli University https://orcid.org/0000-0002-4374-7193

\section{Serap Argun Barış}

Kocaeli University https://orcid.org/0000-0002-4429-9441

\section{Case Report}

Keywords: COVID-19, reinfection, immunity, splenectomy

Posted Date: November 13th, 2020

DOI: https://doi.org/10.21203/rs.3.rs-106603/v1

License: (c) (i) This work is licensed under a Creative Commons Attribution 4.0 International License. Read Full License 


\section{Abstract}

Background: The COVID-19 pandemic has resulted in more than 31 million cases diagnosed and 965,000 deaths as of September 21, 2020. As the number of cases increases, clinical conditions such as prolonged viral release, reinfection, and reactivation are being encountered more frequently.

Case presentation: This article presents a case who was reinfected with COVID-19 and developed a more severe second disease unlike other cases in the literature.

Conclusions: Reinfection in a splenectomy case may help researchers understand the pathogenesis of the disease and can be a guide for the development of vaccines and new treatments.

\section{Background}

In December 2019, cases of pneumonia with unknown causes were reported in Wuhan, China, and a new coronavirus named SARS-CoV-2 was detected in lower respiratory tract samples as an etiological agent (1). The World Health Organization named this virus coronavirus disease 2019 (COVID-19) and officially declared it a pandemic on March 11,2020 as a result of the rapid increase of cases and spread to other countries. As of September 22, 2020, the total number of COVID-19 cases globally was at 31,490,644 and total deaths were at 969,367. In Turkey, the first case was reported on March 11, 2020, and the total number of cases as of September 26, 2020 was 314,413 (5).

The definitive diagnosis of COVID-19 is made by detecting viral RNA in the respiratory samples of patients. The currently recommended medical observation period or containment period for patients with COVID-19 is 14 days. However, prolonged viral RNA shedding is not a rare phenomenon, regardless of symptomatic relief (7). Also, reinfection can be seen patients who have recovered from COVID-19. There have been several case reports of patients getting reinfected with COVID-19 as they tested positive for the virus again after discharge. These cases add to the difficulty of controlling the pandemic. This article presents a case who was reinfected with COVID-19 and developed a more severe second disease unlike other cases in the literature.

\section{Case Presentation}

A 57-year-old male patient was admitted to the hospital with complaints of muscle pain and headache in April 2020. The patient had hypertension and coronary artery disease. In the nasopharyngeal swab, SARS-CoV-2 PCR was positive, and the patient was started on hydroxychloroquine treatment. The patient's admission saturation was $98 \%$ in room air. There were minimal ground-glass densities in the basal areas of the left lower lobe of the left lung on thoracic tomography, and the findings were interpreted as significant in terms of early-stage COVID pneumonia. No abnormality was detected in the patient's hemogram and biochemistry parameters. He was discharged after eight days. Later in July 2020 , the patient applied to our hospital with complaints of muscle pain, cough, shortness of breath, and fever. The patient's SARS-CoV-2 PCR results were found to be positive again. An in-depth look into his 
medical history showed that splenectomy was performed as a result of trauma in 2019. In the thoracic tomography of the patient with $80 \%$ saturation in room air, peripheral and localized multifocal groundglass infiltrations were present in all lobes of the lung parenchyma. It was evaluated to be compatible with moderate/severe COVID involvement. Figure 1 shows the patient's thorax tomography images. In laboratory tests, total leukocyte count: $20,800 / \mu \mathrm{L}$, neutrophil count: $14,700 / \mu \mathrm{L}$, lymphocyte count: 4000 / $\mu \mathrm{L}$, aspartate aminotransferase: $63 \mathrm{U} / \mathrm{L}$, alanine aminotransferase: $65 \mathrm{U} / \mathrm{L}, \mathrm{C}$ reactive protein (CRP): 160 $\mathrm{mg} / \mathrm{L}$, ferritin: $499 \mathrm{ng} / \mathrm{ml}$, fibrinogen: $7.65 \mathrm{~g} / \mathrm{L}$, and d-dimer: $0.73 \mu \mathrm{g} / \mathrm{ml}$ were detected. The patient was started on levofloxacin and favipiravir treatments upon admission to our service. The patient received 4 It/min nasal oxygen support treatment. When his saturation decreased further, $8 \mathrm{lt} / \mathrm{min}$ oxygen was given with a reservoir mask. Favipiravir treatment was extended to 10 days. On the 10th day of treatment, the patient's saturation was $91 \%$ in room air, and CRP, ferritin, and D-dimer tests reached their thresholds. The patient was taken to home isolation for 14 days. The subsequent control SARS-CoV-2 PCR was negative.

\section{Discussion And Conclusion}

The novel coronavirus disease is a pandemic with high fatality rate, especially in the elderly population and patient groups with comorbidities such as hypertension, cardiovascular disease, chronic kidney failure, and cancer (3). As of May 1, 2020, the fatality rate of the infection was determined as $1.4 \%$ (4). The transmissibility of a virus is indicated by its reproductive number (Ro), which shows how fast the virus spreads. Ro was determined to be 3.77 according to clinical and epidemiological data from 8866 patients in 30 provinces, a value higher than the Ro of the severe acute respiratory virus (Ro: $2-3$ ) (6). For this reason, it is difficult to control the pandemic, despite isolation preventions.

Prolonged viral shedding and the possibility of reinfection in some people are other problems that make pandemic management difficult. Virus RNA was reported to have been isolated from the sputum and feces of patients a few weeks after their discharge (8). Another study from Wuhan reported that the virus was detected for a median of 20 days (up to 37 days among survivors) after symptom onset (13). In our case, three months between two infections excludes the possibility of prolonged viral shedding.

Although the causes of COVID-19 reinfection are not yet fully clarified, the number of reported cases is increasing. Reinfection is defined as the detection of SARS-CoV-2 PCR positivity again after two PCR tests taken every 24 hours are negative. Theoretically, the SARS-CoV-2 genome must be the same in both infections. Evidence suggests that possible causes of reinfection include short-lived protective immunity and re-exposure to genetically different forms of the same viral strain (12). Another reason can be crosscontamination from another betacoronavirus, but as in our case, COVID-compatible tomography findings support COVID-19 reinfection (14). Sequencing and phylogenetic analysis of the SARS-CoV-2 genome in reinfection cases may be useful for understanding viral pathogenesis.

The antibody response in patients with COVID-19 remains largely unknown. For the majority of individuals infected with SARS-CoV-2, neutralizing immunoglobulin (IgM and $\operatorname{lgG}$ ) levels rise within days to weeks of symptom onset (10). Many human infections with other viral pathogens, such as the 
influenza virus, do not produce a durable immune response. The durability of IgG against SARS-CoV-2 has yet to be defined; persistence up to 40 days from symptom onset has been reported (11). In our patient, reinfection was expected because the antibody response was not as effective due to the splenectomy. On the other hand, positive RNA tests have been reported despite seropositivity for IgG after the primary infection (9). Jianghong et al. also showed that patients who were admitted to the hospital due to reinfection had the second disease with mild symptoms regardless of the antibody response (15). However, in our patient, extensive lung involvement and severe symptoms developed in the second attack.

Although the detection of antibody levels is important for herd immunity and epidemiological data, natural killer and CD 8+ T cells are the first defense mechanisms against all viral infections. In the absence of protective antibodies (in case of a splenectomy), it is possible that protective mechanisms through other arms of the immune response (memory and cytotoxic T cells) alter the course of the COVID-19 disease upon reinfection (16). Memory T cells have been shown to serve a very important role in the long-term protection against infection from SARS-CoV-2 infection, which is a member of the family Coronaviridae (17).

An antibody test was not performed on our patient because it was thought that there was no effective antibody due to the splenectomy. In this case, reinfection could be explained by a decrease in the amount of memory $T$ cells or the loss of function. Bo et al. demonstrated a drop in $T$ lymphocyte subgroup count in severely ill patients, including deceased patients (18). Zhang et al. also noted that this reduction could be explained by the atrophy of the spleen and lymph node, thereby highlighting the role of SARS-CoV-2 in potentiating cell degeneration (19).

In conclusion, unlike most common cold viruses, immunity to SARS-CoV-2 involves both cell-mediated and humoral responses. Reinfection in a splenectomy case may help researchers understand the pathogenesis of the disease and can be a guide for the development of vaccines and new treatments.

\section{Declarations}

Ethics approval and consent to participate: Not applicable.

Consent for publication: Written informed consent was obtained from the patient for publication of this case report and any accompanying images.

Availability of data and material: Not applicable.

Competing interests: The authors declare that they have no conflict of interest.

Funding: No funding.

\section{Authors' contributions}

Corresponder author (MTD): Have drafted the work

SA: Revise, designof the work 
MS:Interpretation of data

GST: The acquisition,analysis

EA:Design of the work.

All authors have approved the submitted version and have agreed both to be personally accountable for the author's own contributions and to ensure that questions related to the accuracy or integrity of any part of the work, even ones in which the author was not personally involved, are appropriately investigated, resolved, and the resolution documented in the literature.

\section{Acknowledgements}

Not applicable.

\section{References}

1. Zhu N, Zhang D, Wang W, et al. A novel coronavirus from patients with pneumonia in China,2019. N Engl J Med. 2020;382:727-733.

2. COVID-19 Dashboard by the Center for Systems Science and Engineering (CSSE) at Johns Hopkins University (JHU). https://coronavirus.jhu.edu/map.html (Accessed 27 Sep 2020)

3. Jordan RE, Adab P, Cheng KK. Covid-19: risk factors for severe disease and death. BMJ. 2020;368:m1198.

4. https://www.worldometers.info/coronavirus/coronavirus-death-rate/ (Accessed 26 Sep 2020)

5. Zhou F, Yu T, Du R, et al. Clinical course and risk factors for mortality of adult inpatients with COVID19 in Wuhan, China: a retrospective cohort study.Lancet.2020; 395(10229):1054-1062.

6. Kirkcaldy RD, King BA, Brooks JT. COVID-19 and Postinfection Immunity Limited Evidence, Many Remaining Questions. JAMA.2020;323(22):2245-2246.

7. Zhao J, Yuan Q, Wang $H$, et al. Antibody responses to SARS-CoV-2 in patients of novel coronavirus disease 2019. Clin Infect Dis. 2020;ciaa344.

8. Lotfi M, Rezaei N. SARS-CoV-2: a comprehensive review from pathogenicity of the virus to clinical consequences. J Med Virol. 2020;10.1002/jmv.26123.

9. Roy S. COVID-19 Reinfection: Myth or Truth? SN Comprehensive Clinical Medicine 2020;2:710-713.

10. Wölfel R, Corman VM, Guggemos W, et al. Virological assessment of hospitalized patients with COVID-2019. Nature .2020; 581:465-469.

11. Li N, Wang X, Lv T. Prolonged SARS-CoV-2 RNA shedding: Not a rare phenomenon. J Med Virol. 2020;10.1002/jmv.25952.

12. Yang Y, Lu Q, Liu M, et al. Epidemiological and clinical features of the 2019 novel coronavirus outbreak in China. BMJ.2020; https://doi.org/10.1101/2020.02.10.20021675

13. https://covid19.saglik.gov.tr/TR-66935/genel-koronavirus-tablosu.html (Accessed 26 Sep 2020) 
14. Kellam P, Barclay W. The dynamics of humoral immune responses following SARS-CoV-2 infection and the potential for reinfection. Journal of General Virology.2020;101(8):791-797.

15. An J, Liao X, Xiao T, et al. Clinical characteristics of the recovered COVID-19 patients with redetectable positive RNA test.2020; https://doi.org/10.1101/2020.03.26.20044222.

16. Coronaviridae Study Group of the International Committee on Taxonomy of Viruses. The species severe acute respiratory syndrome-related coronavirus: classifying 2019-nCoV and naming it SARSCoV-2. Nat Microbiol. 2020;5:536-44

17. Channappanavar R, Fett C, Zhao J, Meyerholz DK, Perlman S.Virus-specific memory CD8 T cells provide substantial protection from lethal severe acute respiratory syndrome coronavirus infection. Journal of Virology.2014;88(19):11034-11044.

18. Xu B, Fan C, Wang A, et al. Suppressed T cell-mediated immunity in patients with COVID-19: A clinical retrospective study in Wuhan, China. J Infect. 2020;81(1):e51-e60.

19. Zeng G, Xie S, Li Q, Ou J. Infectivity of Severe Acute RespiratorySyndrome during Its Incubation Period. Biomed Environ Sci. 2009;22(6):502-510.

\section{Figures}
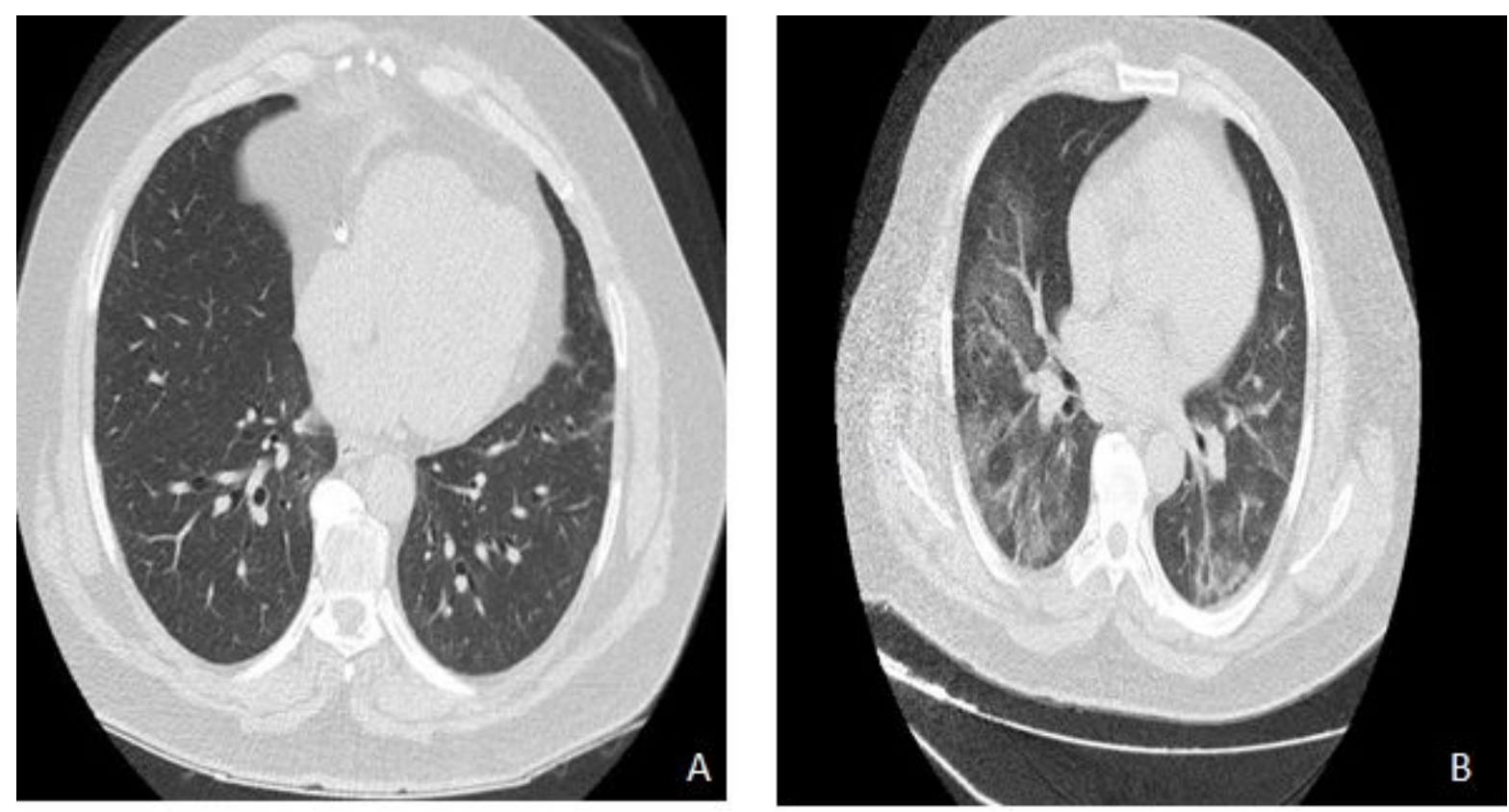

Figure 1

Computarized tomography images of the patient's first COVID-19 infection (A) and reinfection (B) 